\title{
Immunohistochemical study of basement membrane collagen IV in uterine cervix carcinoma
}

\author{
Laboratory of Experimental Pathology, \\ CAISM, Department of Anatomical Pathology, Universidade Estadual de Campinas, São Paulo, Brazil
}

\begin{abstract}
Context: The integrity of basement membrane $(\mathrm{BM})$ is damaged during the evolution of a benign or potentially malignant lesion into a malignant one, in which it may undergo several degrees of discontinuity as a necessary condition for the invasive process. Immunostaining for collagen IV, which is exclusively found in BM, has been used to evaluate its formation in neoplastic and benign lesions of several organs. Objective: To investigate BM continuity pattern in squamous carcinoma "in situ" (CIS), microinvasive (MIC) and invasive (IC) squamous cell carcinoma of the uterine cervix, and to find out if BM expression could be useful in the diagnosis of early stromal invasion (MIC). Design: Archival material between 1988 and 1993 was studied at the Pathological Anatomy Department - Unicamp. Procedures: The selected cases, previously formalin fixed and paraffin embedded, were reviewed retrospectively by submitting them to immunohistochemical study via the avidin-biotin-peroxidase method using a monoclonal antibody anticollagen IV. Results: In all, 17 cases of CIS, 16 of MIC and 21 of IC were evaluated. All IC cases showed evident BM discontinuity, either focal or diffuse. In the CIS group, a continuous BM pattern was predominant, being focally disrupted in only $2 /$ 17 cases (11.8\%). The MIC group showed an intermediate pattern, but with a clear tendency to BM discontinuity in 10/16 cases $(62.5 \%)$. Inflammatory infiltrate, a variable also studied, cannot be considered responsible for BM discontinuity, since there was no statistical correlation between them. Conclusion: We conclude that immunostaining for collagen IV may contribute to the diagnosis of stromal invasion by BM discontinuity.
\end{abstract}

Uniterms: Uterine cervical carcinoma. Basement membrane. Collagen IV. Immunohistochemistry.

\section{INTRODUCTION}

$\mathrm{B}$ asement membrane $(\mathrm{BM})$ is a specialized structure of the extracellular matrix, produced by epithelial, endothelial and some mesenchymal cells. ${ }^{1}$ Its intrinsic components (found exclusively in BM) are collagen IV, laminin and proteoglycane heparin sulfate. ${ }^{2}$ Its function of separating cellular compartments is

\footnotetext{
Address for correspondence:

José Vassallo

Faculdade de Ciências Médicas da Universidade Estadual de Campinas, Departamento de Anatomia Patológica

Caixa Postal 6111

Campinas/SP - Brasil - CEP 13083-970
}

maintained in hyperplastic or hypertrophic processes, but in malignant neoplasia there is BM destruction as a part of the stromal invasion and metastatic process.

The mechanisms through which this occurs are not yet clear and some possibilities have been suggested: a) extracellular matrix component degradation by neoplastic cells; b) decrease or defect in BM component synthesis by neoplastic cells; or c) decreased capacity of tumor cells for restoring the defects produced by inflammatory cells crossing it. ${ }^{3}$

Evidence favoring BM destruction by neoplastic cells includes the identification of type IV specific collagenases. Enzymatic activity is correlated with metastatic potential. ${ }^{4-6}$ Another enzyme, endoglucosidase, which selectively degrades another BM component, proteoglycane heparin 
sulfate, was identified in a melanoma cell lineage. ${ }^{7,8}$ During stromal invasion by a tumor, the proposed sequence of events would be: first, the neoplastic cell binds to extracellular matrix components, such as laminin in BM and fibronectin in the stroma, via surface receptors; then, the tumor cell would secrete hydrolytic enzymes or would induce adjacent normal cells to do so; and finally, locomotion of the neoplastic cell through the degraded area would be facilitated and these events would be repeated cyclically. Nevertheless, the fact that collagenases have also been found in benign neoplastic cells via the in situ hybridization technique shows that the invasive mechanism must be more complex than previously suspected. ${ }^{9}$

The BM can be demonstrated by special stains such as PAS, although these are not specific. ${ }^{10}$ Thus, BM studies have tended to be carried out via immunohistochemical techniques instead, using antibodies against its intrinsic components, especially collagen IV and laminin. ${ }^{11-13}$ These techniques are widely applied in studying neoplasia and it has been observed that pre-malignant, reactive processes, benign tumors and in situ carcinomas are more frequently associated with linear and continuous BM, whereas invasive neoplasia tend to destroy the BM focally or extensively. ${ }^{2,10,14-16}$ These data are also corroborated by ultrastructural studies. ${ }^{17}$

The incidence of uterine cervical cancer is high in Brazil. ${ }^{18}$ Adequate evaluation of the depth of invasion is important in establishing disease staging. ${ }^{19}$ Initial studies with immunofluorescence in frozen sections showed continuous BM in situ (CIS) and invasive epidermoid carcinoma (IC) of the uterine cervix..$^{20}$ Studies using the immunoperoxidase technique of archival material showed progressive discontinuity of the BM with increasing invasion of the cervical stroma. ${ }^{3,21-23}$

The aim of the present study was to evaluate the BM continuity pattern in CIS, microinvasive carcinoma (MIC) and IC of squamous cells by the immunoperoxidase technique in paraffin sections, using anticollagen IV antibody. Our purpose was to see to what extent evaluation of BM continuity may be useful for the pathologist when facing routine cases where invasion is doubtful. Since inflammatory infiltrate has been suggested as playing a role in the destruction of $\mathrm{BM}^{3,24,25}$ we also studied the relationship between inflammatory infiltrate and BM continuity.

\section{METHODS}

Cases of CIS, MIC and IC in squamous cells were selected from the files of the Pathological Anatomy Department,
State University of Campinas (UNICAMP), between 1988 and 1993. All specimens - biopsies, cone or hysterectomy - had been sent to the Department fixed in 10\% formalin and were subsequently embedded in paraffin. Hematoxylin and eosin (H\&E) stained slides were reviewed for diagnosis and the best paraffin blocks of each case were selected for immunohistochemical study (IHC). The avidin-biotinperoxidase technique was used, as previously described. ${ }^{26}$ In short, 5 micrometer paraffin sections were placed on clean slides coated with a PVA- containing glue. Sections were incubated at $60^{\circ} \mathrm{C}$ for $24-48$ hours. Paraffin was removed with xylene and sections were rehydrated via graded alcohols. Enzymatic digestion was performed with pepsin (Sigma P7012) in $100 \mathrm{ml} 0.01 \mathrm{M} \mathrm{HCl}$ for two hours at $37^{\circ} \mathrm{C}$. Where the results were unsatisfactory, alternative protocols were tried. These included microwaving in citrate buffer ( $\mathrm{pH} 6.0$ ) for $2 \times 5$ mins, ${ }^{27}$ and microwaving alone or coupled with enzymatic digestion with pepsin at 30,60 and 90 minutes respectively. After water washing, peroxidase inhibition was accomplished with $3 \%$ $\mathrm{H}_{2} \mathrm{O}_{2}$ in methanol, for 15 minutes at room temperature.

Following washing in PBS buffer (pH 7.6) and incubation for 20 minutes in 1:10 normal horse serum in a humid chamber at room temperature, sections were incubated overnight, at $4^{\circ} \mathrm{C}$ in a humid chamber, with a monoclonal antibody anticollagen IV (1:100) produced in mouse (Dakopatts, Denmark, M785). After that, sections were incubated with anti-mouse horse immunoglobulin biotinylated antibody (Vectastain, PK 4002) for 30 minutes, at RT. Reaction was visualized with 3,3 tetrahydrochloride diaminobenzidine (Sigma, D5637), $40 \mathrm{mg} / 100 \mathrm{ml} \mathrm{H}_{2} \mathrm{O}_{2}$ $30 \%$. Nuclear counterstaining was made with hematoxylin and sections were set up with permanent resin.

The BM pattern was classified as follows:

$\mathrm{A}=$ normal, continuous $\mathrm{BM}$;

$\mathrm{B}=\mathrm{BM}$ showing thinned areas;

$\mathrm{C}=\mathrm{BM}$ showing small discontinuous areas; and

$\mathrm{D}=\mathrm{BM}$ showing either extensive discontinuous areas or absent.

Intensity of inflammatory infiltrate was classified in each case as follows: $0=$ absent; $1+=$ mild; $2+=$ moderate and $3+=$ severe. Intensity of immunohistochemical reaction was also graded as weak (1+), moderate (2+) or intense (3+).

\section{RESULTS}

Between 1988 and 1993, paraffin blocks of 33 cases of ISC, 28 of MIC and 26 of CIS (total = 87 cases) were selected and submitted to IHC study. After this study, 17 
cases of CIS, 16 of MIC and 21 of IC were evaluable by IHC (total $=54$ cases). The remaining $28(32 \%)$ showed no BM staining, even after repeating the technique, whether at the epithelium or at the internal control (blood vessels). Besides that, five cases of MIC showed no more invasive areas in the preparation for IHC.

From the total of 54 cases studied with IHC, biopsies corresponded to 17 , cones to 35 and hysterectomy specimens to two. There was no significant difference between these specimens as to the intensity of immunohistochemical reaction (Table 1). In other words, all material obtained from biopsies, cones or hysterectomy specimens showed similar results when searching for collagen IV by IHC.

The distribution of BM pattern in the 17 cases of CIS, 16 of MIC and 21 of IC are summarized in Table 2. From the 21 cases of IC, three were well-differentiated, 14 moderately and five poorly differentiated carcinoma. Since all cases of IC presented small to large areas of interruption $(100 \%$ pattern $\mathrm{C}+\mathrm{D})$, changes in BM pattern could not be detected in the degree of differentiation in this kind of tumor. When BM patterns were grouped as absence of discontinuity $(\mathrm{A}+\mathrm{B})$ or presence of discontinuity $(\mathrm{C}+\mathrm{D})$ for statistical analysis (Table 2), a strong association could be detected between CIS and BM preservation and between IC and BM discontinuity. The MIC group was situated in an intermediate position. From the latter, 10/16 cases $(62.5 \%)$ showed $(C+$ D) BM discontinuity patterns.

The intensity of inflammatory infiltrate provided averages of $1.353+$ (CIS), 1.905+ (MIC) and 2+ (IC). Regarding this variable, the CIS group differed significantly from IC and there was a tendency to differ from MIC, although with no statistical significance. There was no difference in the intensity of inflammatory infiltrate between the MIC and IC groups.

Regarding the association of BM continuity patterns with intensity of the degree of inflammatory infiltrate (Table 3), there was no statistical significance. This finding shows that the intensity of inflammatory infiltrate should not interfere with BM continuity.

\section{DISCUSSION}

The PAS reaction can be used for evaluating BM and was used for this purpose by Ozzello ${ }^{28}$ in 1959, whose study evaluated BM in breast carcinoma. His findings suggest BM destruction in invasive areas. Nevertheless, as PAS stains glycoproteins without specificity, it is difficult to precisely evaluate areas of $\mathrm{BM}$ destruction since connective tissue around tumor cell nests can be stained as well.
Table 1

Source of specimens vs. intensity of IHC reaction.

\begin{tabular}{lccc}
\hline & \multicolumn{2}{c}{ Intensity } & \\
\cline { 2 - 3 } Source & $\mathbf{+}++$ & $\mathbf{+ + +}$ & Total \\
\hline Biopsies & 07 & 10 & 17 \\
Cones/hysterectomies & 21 & 16 & 37 \\
\hline Total & 28 & 26 & 54 \\
\hline $\mathrm{X}^{2}=1.13 ; \mathrm{DF}=1 ; 0.20<\mathrm{p}<0.30$ & &
\end{tabular}

Table 2

BM continuity pattern in the studied group of lesions.

\begin{tabular}{|c|c|c|c|c|c|}
\hline \multirow[b]{2}{*}{ Diagnosis } & \multicolumn{4}{|c|}{ BM Pattern } & \multirow[b]{2}{*}{ Total } \\
\hline & A & B & C & D & \\
\hline CIS & 6 & 9 & 2 & 0 & 17 \\
\hline MIC & 1 & 5 & 6 & 4 & 16 \\
\hline IC & 0 & 0 & 3 & 18 & 21 \\
\hline Total & 7 & 14 & 11 & 22 & 54 \\
\hline
\end{tabular}

$\mathrm{A}+\mathrm{B}$ and $\mathrm{C}+\mathrm{D}$ were grouped for statistical analysis $-\mathrm{X}^{2} \quad 30.80 ; 2$; $P<0.001$

Table 3

Intensity of inflammatory infiltrate vs. BM pattern.

\begin{tabular}{|c|c|c|c|}
\hline \multirow[b]{2}{*}{ Inflam. infiltrate } & \multicolumn{2}{|c|}{ BM Pattern } & \multirow[b]{2}{*}{ Total } \\
\hline & $(A+B)$ & $(C+D)$ & \\
\hline $0 /+$ & 9 & 10 & 19 \\
\hline$++/+++$ & 12 & 23 & 35 \\
\hline Total & 21 & 33 & 54 \\
\hline
\end{tabular}

$\mathrm{X}^{2} \quad 0.36 ; \mathrm{DF}=1 ; 0.50<\mathrm{p}<0.60$

On the other hand, collagen IV is well-recognized as a BM-exclusive component and can be easily stained by the immunoreaction specific method. The immunohistochemical reaction has a great advantage, as it may be used in archival material, although technical problems must be addressed. The reason for these precautions is mainly the "recovery" of masked antigens during the formalin fixation process. Barsky et al. ${ }^{29}$ compared the pepsin effect to other proteases in antigen unmasking for immunohistochemical detection of collagen IV. The authors concluded that pepsin is the best enzyme, with a digestion time of two hours at $37^{\circ} \mathrm{C}$.

We obtained similar results after testing different proteolytic enzymes and different incubation time. Even using this treatment and trying to improve the results with microwaving, 28 out of 87 cases initially examined (32\%) 


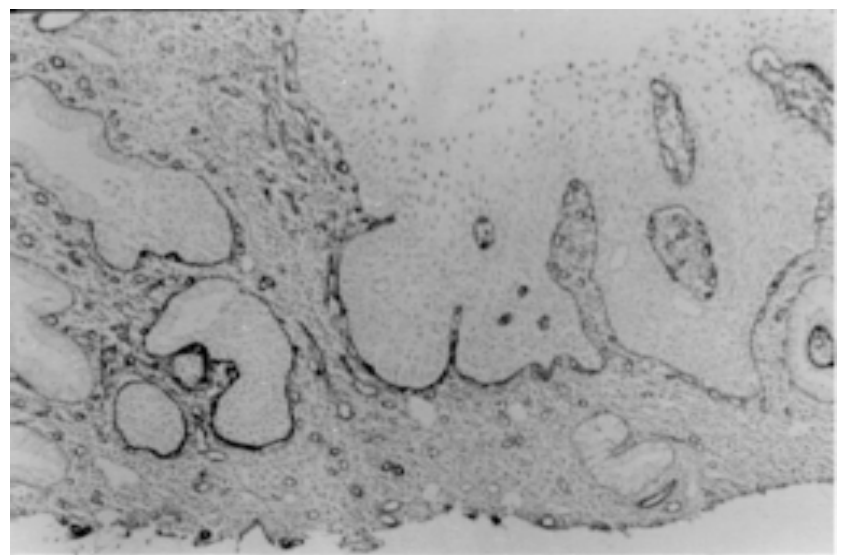

Figure 1 - In situ carcinoma: BM is stained in a continuous line both on the surface and glandular epithelium. (Anti-collagen IV, $132 \mathrm{x}$ ).

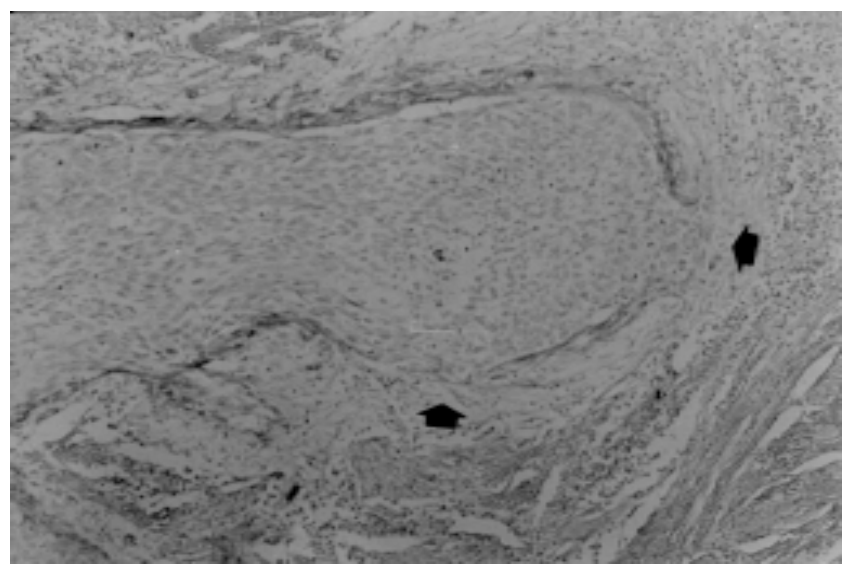

Figure 2 - Microinvasive carcinoma: BM disruption can be observed in early invasion (arrow). (Anti-collagen IV, 264 x).

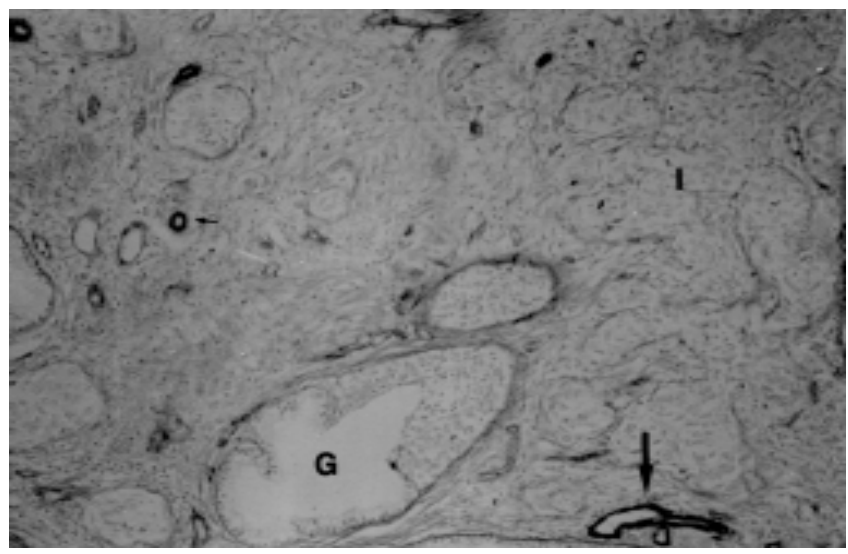

Figure 3 - Whilst areas of in situ carcinoma gland component still present $B M$ integrity $(G)$, no $B M$ is seen in invasive areas (I). Blood vessels (arrow) show strong immunostaining of BM. (Anticollagen IV, $264 \mathrm{x}$ ).

continued to provide negative results, probably by irreversible deleterious action of the fixation process in formalin. Therefore, the use of alcohol-based fixative such as Carnoy or Methacarn has been suggested for collagen IV detection. ${ }^{30}$ However, that is not always possible in a routine diagnostic laboratory. On the other hand, the size of the specimens, represented by biopsies, cones or hysterectomy, did not interfere with the intensity of the immunohistochemical reaction. It is certainly due to the fixative passing through the epithelium and the underlying BM being preserved with the same quality in any kind of material.

The analysis of our results shows that most IC causes large areas of BM interruption ( $\mathrm{D}=18 / 21$ cases). In $3 / 21$ cases, there was scattered BM discontinuity and in no case was it totally intact. These features did not depend on the degree of histological differentiation of the carcinoma. It is known that invasive carcinoma may present continuous $\mathrm{BM}$ around cell nests, although our data are not in agreement with other studies which describe predominantly intact $\mathrm{BM}$ in invasive epidermoid carcinoma of the uterine cervix. ${ }^{20}$

By comparing CIS and MIC we observed that BM shows increasing damage. $15 / 17$ cases of CIS presented continuous membrane patterns (A and B) and only $2 / 17$ had scattered interruption areas, whilst more than half of MIC cases presented BM damage, that is, 10/16 cases $(62.5 \%)$ were mainly composed of either small areas (6/ 16) or large areas (4/16) of discontinuity. These data are in accordance with previous studies showing evident and increasing degrees of BM damage as the invasive process of carcinoma develops. ${ }^{3,22}$

Nevertheless, we observed that the isolated study of collagen IV staining is not definitive for the determination of the presence of early invasion. There is a clear difference in BM patterns between in situ and invasive carcinoma, even though a few cases of CIS presented discontinuous areas of BM (12\%) and some cases of MIC had continuous BM (37.5\%). Thus, we should emphasize that BM immunostaining should always be evaluated in association with conventional morphology. Its diagnostic utilization in doubtful cases of early invasion is a valuable tool which may contribute to distinguishing these entities, especially when there is BM discontinuity. That happened in most of our MIC cases. Another limitation which should be considered when evaluating immunostaining for collagen IV is that microinvasion may be a focal process, not showing up in subsequent sections for immunohistochemistry, as was the case in 5 of our MIC cases.

As for the role of inflammatory infiltrate in BM damage, our data show that there is no relationship between intensity of inflammation and BM discontinuity. These data corroborate with Ehrmann et al, ${ }^{31}$ as opposed to Stenbäck et al. ${ }^{21}$ and Richards \& Furness. ${ }^{3}$ These latter authors had suggested that inflammatory infiltrate would play a deleterious role in uterine cervical carcinoma. Visser et al. ${ }^{32}$ stated the same by studying laryngeal dysplasia and carcinoma. 
Induction of BM injury by granulocytic inflammatory cells can be understood since they produce type IV collagenase. ${ }^{24}$ However, most of our cases showed predominantly lymphocytic inflammatory infiltrate. Although in vitro studies demonstrate that $\mathrm{BM}$ components stimulate lymphocyte and tumoral cell adhesion and mobility, modulating their activity, ${ }^{25}$ knowledge about the interrelation between neoplastic cells, BM and lymphocytes is still deficient. The role of inflammatory infiltrate in the invasive process of uterine cervical

\section{REFERENCES}

1. Yurchenco PD, Schittny JC. Molecular architecture of basement membranes. FASEB J 1990;4:1577-90.

2. Martinez-Hernandez MD, Amenta SP. The basement membrane in pathology. Lab Invest 1983;656-77.

3. Richards CJ, Furness PN. Basement membrane continuity in benign, premalignant and malignant epithelial conditions of the uterine cervix. Histopathology 1990;16:47-52.

4. Liotta LA, Abe SD, Robey PG, Martin GR. Preferential digestion of basement membrane collagen by and enzyme derived from a metastatic murine tumor. Proc Natl Acad Sci 1979;76:2268-75.

5. Barsky SH, Togo S, Garbisa S, Liotta LA. Type IV collagenase immunoreactivity in invasive breast carcinoma. Lancet 1983a;5:296-7.

6. Shields SE, Ogilvie DJ, McKinnell RG, Tarin D. Degradation of basement membrane collagens by metaloproteases released by human murine and amphibian tumours. J Pathol 1984;143:193-7.

7. Kramer RH,Vogel G, Nicolson GL. Solubilization and degradation of subendothelial matrix glycoproteins and proteoglycanes by metastatic tumor cells. J Biol Chem 1982;257:2678-86.

8. Kramer RH, Vogel G, Kathryn G. Selective degradation of basement membrane macromolecules by metastatic melanoma cells. J Natl Cancer Inst 1984;72:889-97.

9. Soini Y, Autio-Harmainen H. Synthesis and degradation of basement membranes in benign and malignant salivary gland tumours: a study by in situ hybridization. J Pathol 1993;170:291-6.

10. Barsky H, Siegal GP, Jannotta F, Liotta LA. Loss of basement membrane components by invasive tumors but not by their benign counterparts. Lab Invest 1983;49:140-7.

11. Havenith MG, Cleutjens JPM, Beek EC, Vander Liden E, De-Goey AFPM, Bosman FT. Human specific anti-type IV collagen monoclonal antibodies, characterization and immunohistochemical application. Histochemistry 1987;87:123-8.

12. Foelmer HG, Madri JA, Furthmayr H. Methods in laboratory investigation: monoclonal antibodies to type IV collagen: carcinoma remains to be settled, since it had a propensity to be less intense in the CIS group in our study. We believe denser lymphocytic infiltrate is a signal suggesting initial neoplastic invasion, but with our data such infiltrate cannot be held responsible for BM injury or discontinuity.

Thus, immunostaining for collagen IV may be an important aid in diagnosing early invasion in uterine cervical carcinoma. Our data favor the diagnosis of early or clear-cut invasion in the presence of BM discontinuity.

probes for study of structure and function of basement membranes. Lab Invest 1983;48:639-49.

13. Barsky SH, Baker A, Siegal GP, Togo S, Liotta LA. Use of anti-basement membrane antibodies to distinguish blood vessel capillaries from lymphatic capillaries. Am J Surg Pathol 1983;7:667-77.

14. Albrechtsen R, Nielsen M, Wewer U, Engvall E, Ruoslahti E. Basement membrane changes in breast cancer detected by immunohistochemical staining for laminin. Cancer Res 1981;41:5076-81.

15. Liotta LA, Tryggvason K, Garbisa S, Hart I, Foltz CM, Shafie S. Metastatic potential correlates with enzymatic degradation of basement membrane collagen. Nature 1980;284:67-8.

16. Birembaut P, Caron Y, Adnet JJ, Foidart JM. Usefulness of basement membrane markers in tumoural pathology. J Pathol 1985;145:283-96.

17. Bosman FT, Havenith M, Cleutjens JPM. Basement membranes in cancer. Ultrastructural Pathol 1985;8:291-304.

18. Lopes de Faria J, Milani VP, Albino Filho J, Moreira Filho DJC. Geographic pathology and epidemiology of cancer in Brazil (South America). In: Grundmann E, editor. Cancer Epidemiology (1982) Cancer Campaign, vol.6. New York: Gustav Fischer Verlag Stuttgart 1982;71-87.

19. Figo news: modifications in the staging for stage I vulvar and stage I cervical cancer. Int J Gynecol Obst 1995;50:215-6.

20. Frappart L, Berger G, Grimaud JA, et al. Basement membrane of the uterine cervix: immunofluorescence characteristics of the collagen epithelium and invasive carcinoma. Gynecol Oncol 1982;13:58-66.

21. Stenbäck F, Wasenius VM, Ristelli J, Ristelli L. Basement membrane in progressing intraepithelial cervical neoplasia: an ultrastructural and immunohistochemical study with antibodies against human type IV collagen and laminin. Gynaecol Obstet Invest 1985;20:158-66.

22. Favret M, Parolini S, Rosa D, et al. Localizzazione immunoistochimica di laminina, collagene IV e fibronectina nelle displasie e neoplasie della cervice uterina. Pathologica 1990;82:479-86.

23. Pitt MA, Hall RJ, Bucklly CH. The distribution of type IV collagen in invasive carcinoma of the uterine cervix. Histopathology 1992;20:139-43. 
24. Uitto VT, Schwartz D, Vers A. Degradation of basement membrane collagen by neutral proteases from human granulocytes. Eur J Biochem 1980;105:409-17.

25. Li YY, Cheung HT. Basement membrane and its components on lymphocyte adhesion, migration and proliferation. J Immunol 1992;149:3174-81.

26. Hsu SM, Raine L, Fanger H. A comparative study of the peroxidase-antiperoxidase method and avidin-biotin complex method for studying polypeptide hormones with radioimmunoassay antibodies. Am J Clin Pathol 1981;75:734-8.

27. Cattoretti G, Suurmeijer JH. Antigen unmasking on formalin-fixed paraffin-embedded tissues using microwaves: a review. Adv Anat Pathol 1995;2:2-9.

28. Ozzello L. The behavior of basement membranes in intraductal carcinoma of the breast. Am J Pathol 1959;35:887-99.

29. Barsky SH, Rao NC, Restrepo C, Liotta LA. Immunocytochemical enhancement of basement membrane antigens by pepsin: applications in diagnostic pathology. Am J Clin Pathol 1984;82:191-4.

30. Lee AK. Basement membrane and endothelial antigens: their role in evaluation of tumor invasion and metastasis. In: De-
Lellis RA, editor. Advances in immunohistochemistry. New York: Raven Press 1988;363-93.

31. Ehrmann RL, Dwyer IM, Yavner D, Hancock WW. An immunoperoxidase study of laminin and type IV collagen distribution in carcinoma of the cervix and vulva. Obstet Gynecol 1988;72:257-62.

32. Visser R, Van Der Beek JMH, Havenith MG, Cleutjens JPM, Bosman FT. Immunocytochemical detection of basement membrane antigens in the histopathological evaluation of laryngeal dysplasia and neoplasia. Histopathology 1986;10:171-80.

\section{ACKNOWLEDGMENTS}

The authors are indebted to Drs. Venâncio A. F. Alves, Francesco Langone, Maria Regina Viana and Jessé P. Jorge for critical review of the manuscript and to Mrs. Rosemeire F. Dionísio for secretarial assistance.

\section{RESUMO}

Contexto: A integridade da membrana basal (MB) é destruída no processo de evolução de uma lesão benigna ou potencialmente maligna para uma lesão maligna, onde ela pode sofrer vários graus de descontinuidade, como condição necessária para o processo de invasão. A imunocoloração para colágeno IV, que é exclusivamente encontrado na MB, tem sido utilizada para avaliar sua formação em processos benignos e neoplásicos de vários órgãos. Objetivo: Investigar o padrão de continuidade da MB no carcinoma in situ (CIS), microinvasivo (CMI) e epidermóide (CE) do colo uterino. Além disso, pretendeu-se verificar em que medida estes padrões poderiam ser úteis no diagnóstico de invasão estromal inicial (CMI). Tipo de Estudo: Foi estudado o material do arquivo de tecidos dos anos de 1988 a 1993 do Departamento de Anatomia Patológica da UNICAMP. Procedimentos: Os tecidos eram fixados em formalina e incluídos em parafina e foram revistos retrospectivamente para serem submetidos à reação imuno-histoquímica pelo método da avidina-biotina-peroxidase, com o anticorpo monoclonal anticolágeno IV. Resultados: Ao todo, foram avaliados 17 casos de CIS, 16 de CMI e 21 de CE. Todos os casos de CE mostraram evidente descontinuidade da MB, quer focal ou difusa. No grupo dos CIS foi observado um padrão contínuo de MB, sendo focalmente lesado em apenas $2 / 17$ casos (11,8\%). O grupo dos CMI mostraram um padrão intermediário, com clara tendência à descontinuidade da MB em 10/16 casos (62,5\%). O infiltrado inflamatório, variável também estudada, não pode ser responsabilizado pela descontinuidade da $\mathrm{MB}$, já que não houve correlação estatística entre eles. Conclusão: $\mathrm{A}$ imunocoloração para colágeno IV pode contribuir no diagnóstico de invasão estromal, quando houver lesão da MB. 